\title{
CRIMINAL TRIALS AND APPEALS: A COMPARISON BETWEEN THE NEW ZEALAND MILITARY JUSTICE SYSTEM AND THE CIVILIAN JUSTICE SYSTEM
}

\section{Christopher Corns*}

\begin{abstract}
This article sets out the laws relating to criminal trials conducted in the Court Martial of New Zealand and relating to appeals from that Court to the Court Martial Appeal Court and compares those laws to the equivalent laws relating to criminal trials and appeals in the civilian system. The purpose of this article is to identify the legal and ideological similarities and differences between the two systems, and where there are differences, to suggest possible explanations. It is argued in this article that, whilst there remain significant differences between the laws governing the military and civilian systems, a clear pattern of "convergence" or "alignment" can be identified whereby the military system is adopting (and adapting) more and more features of the civilian laws in terms of substantive rights, procedure and values. Recent statutory reforms in 2018 to the military justice system are also included. This process of alignment is likely to continue in the future. Having said this, the fundamental differences between the two systems are also likely to remain for some time as each system serves different needs.
\end{abstract}

\section{INTRODUCTION}

In New Zealand, as in other Commonwealth countries, there are two fundamental systems for the administration of criminal justice. ${ }^{1}$ The first, and most high-profile, is the civilian system. In very broad terms, the civilian system is based upon a range of criminal offences which apply to all citizens

* LLB, University of Melbourne, BA (Hons), University of Melbourne, LLM, Monash University, PhD, Monash University, Barrister and Solicitor of the Supreme Court of Victoria; and Honorary Associate Professor, School of Law, La Trobe University, Melbourne.

1 This article is based on research for ch 8 of Christopher Corns and Douglas Ewan "Appeals from the Court Martial of New Zealand to the Court Martial Appeal Court" in Criminal Appeals and Reviews in New Zealand (Thomson Reuters, Wellington, 2019). I am indebted to Judge Advocate General Kevin Riordan, Christopher Griggs, Barrister and Thomas Hague, Assistant Director of the New Zealand Defence Force Legal Services, for their assistance with this research. 
of New Zealand, where a breach of any of those offences will usually be dealt with in the relevant court. ${ }^{2}$ If there is to be a trial, the trial is presided over by a judge only or the trial is conducted as a judge and jury trial - depending upon the category of offence involved. ${ }^{3}$ Key statutes such as the Criminal Procedure Act 2011, the Evidence Act 2006 and the Sentencing Act 2002 apply. ${ }^{4}$ Appeals from these courts are to the "first appeal court". ${ }^{5}$ Further appeals are also possible with leave of the relevant appeal court. ${ }^{6}$ Prosecutions are, in general, conducted by Crown Solicitors, although private prosecutions are recognised. ${ }^{7}$

The second system is the criminal justice system administered by, and within, the New Zealand Defence Force: the "military justice system". ${ }^{8}$ The military justice system consists of (a) the summary disposition of the less serious offences; ${ }^{9}$ and (b) the Court Martial dealing with the more serious offences. This article only concerns proceedings by Court Martial and appeals from that Court.

In broad terms, the military justice system is based upon a range of criminal offences which can apply to persons who are subject to the Armed Forces Discipline Act 1971 (AFDA) (service

2 Investigators and prosecutors do however have a discretion to divert known offenders in particular circumstances, or to grant an immunity from prosecution in appropriate cases: see Criminal Procedure Act 2011, s 148

3 Category 1 and 2 offences are dealt with by a judge-alone trial. A defendant has the right to elect for a jury trial if he or she is charged with a category 3 offence: Criminal Procedure Act, s 50. Category 4 offences are dealt with in the High Court by jury trial if the defendant pleads not guilty.

4 A range of other Acts can of course also apply. Examples include the Bail Act 2000, the Criminal Disclosure Act 2008, the Parole Act 2002 and the Criminal Procedure (Mentally Impaired Persons) Act 2003. The Criminal Procedure Rules 2012 and the Court of Appeal (Criminal) Rules 2001 are also important.

5 The first appeal court depends upon which court was the court at first instance. For example, if the defendant is convicted in the District Court following a judge-alone trial, the first appeal court (for a conviction or sentence appeal) is the High Court: Criminal Procedure Act, s 230(b). If the defendant is convicted in the District Court following a jury trial, the first appeal court (for a conviction or sentence appeal) is either the Court of Appeal or the Supreme Court: Criminal Procedure Act, s 230(b)(i).

6 For example, if the offender unsuccessfully appealed conviction to the High Court, then he or she can apply for leave to appeal the decision of the High Court to either the Court of Appeal or the Supreme Court: Criminal Procedure Act, s 238(b).

7 Criminal Procedure Act, s 10.

8 The Defence Force refers to the Armed Forces and the civil staff within the Defence Force: Defence Act 1990, s 11(1). The Armed Forces consist of the Navy, the Army, and the Air Force collectively, but does not include any part of the cadet forces: Armed Forces Discipline Act 1971 (AFDA), s 2.

9 Summary offences are dealt with by the commanding officer of the accused person: see Chris Griggs "A New Military Justice System for New Zealand" (2006) 45 Military Law and the Law of War Review 287 at 291301. 
offences). ${ }^{10}$ In addition, persons who are subject to the AFDA can also be charged with an offence which would be an offence under a civilian statute. ${ }^{11}$ All of these offences, as well as the investigatory and adjudication procedures, are set out in the AFDA. ${ }^{12}$ The AFDA applies mainly to full-time members of the New Zealand Armed Forces but can, in limited circumstances, also apply to a range of other persons, including some civilians, as discussed below.

A breach of any of these offences can be dealt with in the Court Martial of New Zealand. ${ }^{13}$ If there is to be a trial, the trial is presided over by a judge, along with either three or five military members, depending upon the seniority of the accused and the seriousness of the offence. ${ }^{14}$ Appeals from the Court Martial are to the New Zealand Court Martial Appeal Court (CMAC).

A different set of statutes apply to military trials and appeals. The key statutes are the AFDA, the Court Martial Act 2007 (CMA), the Court Martial Appeals Act 1953 (CMAA), the Armed Forces Discipline Rules of Procedure 2008, the Armed Forces Discipline Regulations 2008 and the Court Martial Appeal Court Rules 2008. These statutes provide the overall legislative framework for the administration of criminal justice in the military system.

A number of vital elements or principles underpin the military justice system. These are the need to maintain discipline, consistency in all strategic environments, portability, expedition, fairness,

10 These service offences are found in the AFDA pt 2, ss 23-73. Many of these offences have a very long heritage, for example, mutiny (s 32), cowardly behaviour (s 28), spying (s 26), drunkenness (s 34), disobeying a lawful command (s 38) and desertion (s 47).

11 Pursuant to s 74(1) of the AFDA. Common examples are offences under the Crimes Act 1961 and the Misuse of Drugs Act 1975. For these offences, and for offences listed in the AFDA, a commanding officer must first record a "well founded" allegation in the form of a charge to be investigated in the prescribed manner, or cause the allegation to be referred to the appropriate civil authority for investigation: AFDA, s 102(1). The Director of Military Prosecutions subsequently decides if the accused is to be committed for trial in the Court Martial, and, if so, upon what charges, and prepares and certifies the charge sheet. The Director then gives a copy of the charge sheet to the accused and lays the charge sheet before the Registrar of the Court Martial: AFDA, s 101F. For some civilian offences there therefore exists concurrent jurisdiction between the military jurisdiction and the civilian system. For details of how the concurrent jurisdiction is resolved, see New Zealand Defence Force Manual of Armed Forces Law Volume 1: Commander's Handbook on Military Law (DM 69 (2 ed)) at [2.7.3].

12 Manual of Armed Forces Law Volume 1: Commander's Handbook on Military Law, above n 11, sets out the investigatory, prosecutorial, and appellate procedures for summary offences in ch 7; and New Zealand Defence Force Manual of Armed Forces Law Volume 2: Commander's Handbook on Military Law (DM 69 (2 ed)) sets out the investigatory, prosecutorial, and appellate procedures for offences dealt with by the Court Martial at [1.1]-[1.8].

13 Court Martial Act 2007 (CMA), s 36, referring to AFDA, s 78.

14 To be a member of a Court Martial, the officer must be a member of the Armed Forces, have served in the Forces for a period of more than three years, and not be disqualified under s 23 of the Act: CMA, s 22. 
efficiency and simplicity. ${ }^{15}$ These elements have arisen from the practical realities of operational conflict and have informed military justice procedures and rights since the advent of courts martial.

Whilst the civilian and military justice systems have been operating in parallel since the colonisation of New Zealand, it would appear that, as a general proposition, less is known about the military justice system by the general public and probably civilian lawyers, than is known about its civil counterpart.

However, for the approximately 11,500 members of the Armed Forces, ${ }^{16}$ the right to a fair trial and the right to appeal a conviction, sentence, ruling, or other decision of the trial court, is just as important as for their civilian counterparts, particularly where the offence involved carries a sentence of life imprisonment.

In general, the New Zealand Bill of Rights Act 1990 (NZBORA) applies equally to all New Zealand citizens regardless of whether they are in the military or not. However, as will be seen in the discussion below, not all provisions in the NZBORA will apply in exactly the same manner for military members. This is because, in joining the Defence Force, members do not lose their rights under the NZBORA, but they do take on additional responsibilities and duties (which their civilian counterparts do not), ${ }^{17}$ and those additional responsibilities affect the way the NZBORA applies to them. The requirement to maintain discipline in the Defence Force can also influence the way in which the NZBORA applies to members of the Defence Force.

In order to "open up" discussion concerning the New Zealand military justice system, this article sets out specific laws in respect of criminal trials conducted in the Court Martial, and appeals to the CMAC, and compares those laws to the equivalent laws in respect of criminal trials and appeals in the civilian system. The purpose of the article is to identify the similarities and differences between the two systems and, where there are differences, to suggest explanations. This comparative analysis also illuminates the ways in which criminal appeal systems in general evolve over time to meet the needs of the institutions and parties involved.

A comparative analysis is also useful because both the military and civilian criminal justice systems have undergone major reforms over the last decade in order to consolidate and modernise old laws. ${ }^{18}$ An important driver of these reforms for both systems has been the requirement that both

15 Referred to by the Minister of Defence, the Hon Phil Goff, during the first reading speech of the Armed Forces Law Reform Bill 2007 (108-10): see (15 March 2007) 637 NZPD 8064-8065. Also see Griggs, above n 9, at 291

16 New Zealand Defence Force Annual Report: For the year ended 30 June 2017 at 23.

17 Froggatt $v$ R (1992) 9 CRNZ 181 (CMAC) at 20.

18 In 2002, a military justice review commenced within the New Zealand Defence Force: see Griggs, above n 9, at 291. As a consequence of the 2002 review, the Armed Forces Law Reform Bill introduced significant 
systems are human rights compliant, particularly after the enactment of the NZBORA. The rights of crime victims have also been a focus.

The Military Justice Legislation Amendment Act 2018 introduced a number of reforms which came into effect on 30 November 2018. ${ }^{19}$ These are discussed below.

As stated, one key feature of all military laws pertaining to trials, sentencing and appeals, is the quintessential need for discipline within the Armed Forces. In a sense, the military operates upon an assumption that all members will obey lawful orders of a superior officer, and this assumption is carried through into legal procedures and legal rights. The requirement of discipline is a core imperative amongst other values, beliefs and customs within the military. These values and beliefs are not generally found in the civilian system.

It is argued in this article that whilst a clear pattern of "convergence" or "alignment" between the military justice system and the civilian justice system can be identified, it is most unlikely that the fundamental features of the military justice system will change in the near future. This convergence consists of the military system adopting (and adapting) features of the civilian system in terms of substantive rights, procedure and underlying values. The convergence is more marked in the military appellate system than in the trial system.

Part I of the article sets out the laws governing the Court Martial (in comparison to civilian courts) and Part II sets out the laws governing appeals from the Court Martial to the CMAC and other forms of review (in comparison to civilian appeal courts).

\section{PART I}

\section{A The New Zealand Court Martial}

The contemporary Court Martial is established by s 8(1) of the CMA. The Court Martial is a single, permanent court of record. Prior to 2007, the system of courts martial was very much ad hoc, based on old rules and procedures, many from the 19th century. ${ }^{20}$ The Court Martial as a whole

reforms in 2007. For the purposes of this article, in the civilian system the Criminal Procedure Act, the Senior Courts Act 2016 and the Court Matters Act 2018 are the most significant reforms.

19 The main reforms introduced by the Military Justice Legislation Amendment Act 2018 are (in summary): the expansion of the rights of victims of crime; the prosecution's right to object to appointment of a military member; abolition of the legal burden of proof on accused; and the expansion of appeal rights in respect of unfitness to stand trial.

20 Prior to 2007, courts martial procedures were largely governed by pt 6 of the AFDA. Part 6 was repealed by s 86 of the CMA. The military use of courts martial can be traced back to at least the 12th century in England. There are records of the Romans taking a military tribunal along with the army into battle: see Gordon Hook "The Evolution of New Zealand Military Tribunals: From Prototype to Paradigm" [2003] New Zealand Armed Forces Law Review 36. The early use of courts martial was based on the need for speedy and efficient 
consists of one judge who is the Chief Judge of the Court Martial and at least six other judges. The judges are civilian judges. ${ }^{21}$ As civilian judges, they enhance independence in trial decision-making, but may lack deep understanding of the military ethos, beliefs and customs. For this reason it is important that the Court also consist of military members as the fact finders.

As mentioned in the introduction, the Court Martial has jurisdiction in respect of service offences as well as civilian offences. Based on the seriousness of these offences, the Court Martial has the criminal jurisdiction equivalent to that of the District Court and the High Court. ${ }^{22}$

\section{B Jurisdiction of the Court Martial}

\section{Service offences}

Section 36(1) of the CMA states that the Court has the jurisdiction conferred by s 78 of the AFDA. Section 78 states:

Subject to the provisions of this Act, the Court Martial has jurisdiction to try any charge against a person subject to this Act in respect of an offence against this Act, whether committed in New Zealand or elsewhere.

Section 78 refers to offences against the AFDA. Part 2 of the Act headed "[o]ffences" sets out 11 categories of offences. Most of these offences are specifically service offences or service related offences relating to the fundamental duties of service members. Examples include "[o]ffences involving treachery, cowardice, and looting" (e.g. aiding the enemy, ${ }^{23}$ cowardly behaviour, ${ }^{24}$ spying $^{25}$ and looting. ${ }^{26}$ Other examples are "[o]ffences involving mutiny" (e.g. mutiny) ${ }^{27}$ and "[d]esertion, absence and malingering". ${ }^{28}$ These could be described as the "core" offences dealt with

despatch of proceedings, not because of any disdain for formal procedures, but simply as a consequence of the exigencies of armed conflict.

21 Judges are appointed from District Court Judges or can be a person who has held a practising certificate as a barrister or solicitor of the High Court for at least seven years: CMA, s 11(1). A District Court Judge appointed to the Court Martial can sit in the Court Martial as a District Court Judge under s 11(2).

22 Most of the offences within the jurisdiction of the Court Martial are equivalent to category 3 or 4 offences, based on the available maximum penalty.

23 Section 23.

24 Section 28.

25 Section 26.

26 Section 31.

27 Section 32.

28 Section 47. 
by the Court and each has a long military history. Any person who is "subject to this Act" could be tried for these offences.

Note the alleged offence can occur anywhere in New Zealand and anywhere in the world: the AFDA has extra-territorial jurisdiction. ${ }^{29}$

\section{Civilian offences}

Another category of offences in the AFDA which comes within s 78 are offences covered by s 74 . Section 74, headed "[o]ffences against the civil law of New Zealand" states:

Every person subject to this Act commits an offence against this section who, whether in New Zealand or elsewhere, does or omits any act which would, if done or omitted in New Zealand, be an offence against any Act other than this Act (in this section referred to as a civil offence).

Again, s 74 applies to an alleged offence whether committed in New Zealand or anywhere in the world. Accordingly, offences under civilian statutes (such as the Misuse of Drugs Act 1975 or the Crimes Act 1961) can be laid in the Court Martial and dealt with as if they were military offences. In a sense, these "civilian" offences become military offences because they are committed by a service member.

Whilst these civilian offences may have concurrent jurisdiction with military and civilian courts, some civilian offences are considered so serious that it is more appropriate for them to be dealt with in a civilian court. For example, except with the consent of the Attorney-General, the Court Martial has no jurisdiction in respect of treason, murder, manslaughter, sexual violation or bigamy committed in New Zealand. ${ }^{30}$

The maximum sentence for service offences varies from life imprisonment ${ }^{31}$ to six months imprisonment. ${ }^{32}$ Some of the offences are equivalent to certain category 4 offences listed in the Criminal Procedure Act. ${ }^{33}$ This means the jurisdiction of the Court Martial is analogous to the jurisdiction of the District Court and the High Court.

\section{Other Matters Within Jurisdiction}

Section 36(2) of the CMA also states that the Court Martial must sit to hear and determine:

29 Section 4

30 AFDA, s 74(4).

31 For example aiding the enemy (s 23), spying in ships or establishments abroad (s 26), cowardly behaviour (s 28) and mutiny (s 31).

32 For example avoidance of duty (s 49), being in possession of alcohol in a ship, establishment, camp, or base (s 52) and false statements on appointment or enlistment (s 53).

33 For example, treason: see Criminal Procedure Act, sch 1. 
- $\quad$ every charge laid before the Registrar by the Director of Military Prosecutions;

- $\quad$ every application by the Director of Military Prosecutions under s 63(2) (i.e. bringing an offender before the court for sentence); and

- $\quad$ every other application made to the Court (e.g. an application for bail).

\section{Who is Subject to the Armed Forces Discipline Act 1971?}

Only persons who are subject to the AFDA can be charged and tried in the Court Martial. The categories of persons who are subject to the Act are very extensive and close reading of the relevant sections is required. ${ }^{34}$ For the purposes of this article, the following persons are subject to the AFDA:

- All officers of the Navy, Army, or Air Force (including officers of the Reserves and Territorial Forces) (s 6);

- $\quad$ Other ranks of the regular forces (s 6);

- A member of the New Zealand Armed Forces temporarily attached to the forces of another country or who is a member of a United Nations force (s 8);

- A member of the Armed Forces of another country, temporarily attached to the Armed Forces of New Zealand (s 9);

- Volunteers, during their period of service, training or exercise (s 10);

- Members of the armed forces of another country undergoing training in the New Zealand Armed Forces (s 11);

- $\quad$ Prisoners of war, subject to the Geneva Convention and the exemptions listed in s 12(2);

- $\quad$ A person charged under s 26 or s 27 (spying), until the charge is finalised (s 13);

- Passengers in any ship, aircraft or vehicle of the New Zealand Armed Forces, in New Zealand or elsewhere "to such an extent as may be prescribed" (s 15);

- $\quad$ Civilians employed by, or accompanying, any New Zealand force on active service "while so employed or while accompanying the force" (s 16);

- A member of the Armed Forces sentenced to imprisonment or detention and dismissed from the force, until the sentence is served (s 17);

- A person who was a member of the Armed Forces but has ceased to be subject to the Act, and is charged with an offence alleged to have been committed when he or she was a member of the Armed Forces, until the charge is disposed of (s 18); and

- $\quad$ Civilians serving outside New Zealand, in a capacity connected with the Armed Forces as specified in Defence Force Orders.

34 The categories are set out in the AFDA pt 1, ss 6-22 and sch 1. Time limitations for charging a person can apply under s 20 and double jeopardy principles apply under ss 21 and 22. 


\section{$E$ Role of the Director of Military Prosecutions}

The office of Director of Military Prosecutions (DMP) performs a crucial role in the military justice system. ${ }^{35}$ The DMP is analogous to the civil role of a Crown Solicitor in New Zealand, or the role of the Director of Public Prosecutions in those commonwealth jurisdictions where the office of Director of Public Prosecutions is recognised. ${ }^{36}$ The DMP is responsible for deciding whether to place the accused on trial, and, if they decide to do so, responsible for deciding the nature of the charges, laying the charges before the Registrar of the Court Martial and appointing a prosecutor. ${ }^{37}$

Under the new s 198C of the AFDA (inserted on 30 November 2018) the DMP must ensure that victims of specified offences are accorded the rights set out in the new pt 10A of the Act.

The DMP shares the same type and degree of independence in office as a Crown Solicitor. For example, the DMP is not subject to the control of the Minister of Defence in the performance of his or her role. ${ }^{38}$ This ensures the DMP is not influenced by political considerations in the exercise of his or her discretionary powers. Further, the DMP is not under the command of any superior officer within the Armed Forces. ${ }^{39}$ However, the DMP must be accountable in some way for the performance of his or her functions and one way this is achieved is through the provision of an annual report to the Solicitor-General. ${ }^{40}$

Further, s 101K(1) of the AFDA provides: ${ }^{41}$

In performing functions or duties, or exercising powers, imposed or conferred by this Act, by the Court

Martial Act 2007, or by the Court Martial Appeals Act 1953, the Director of Military Prosecutions must

35 The position of Director of Military Prosecutions (DMP) was created in 2007 as part of the broader reforms to military justice: see Griggs, above n 9, at 309. The position of DMP creates a clear separation between investigative functions and prosecutorial functions and a clear separation between Ministerial or executive government decision-making and prosecutorial decision-making. The requirement of prosecutorial independence is crucial in this setting.

36 In all Australian jurisdictions, the position of Director of Public Prosecutions is recognised: see Christopher Corns Public Prosecutions in Australia: Law, Policy and Practice (Thomson Reuters, Sydney, 2014) at 19.

37 CMA, s 101F. The DMP can also decide if separate trials will be held and can order a stay of proceedings. See Armed Forces Discipline Regulations 2008, r 62 (drawing charges) and r 122 (charge withdrawal).

38 AFDA, s 101I(a).

39 AFDA, s 101I(b)

40 AFDA, s 101J.

41 The DMP is not obliged to comply with s $101 \mathrm{~K}(1)$ if he or she thinks to do so would be inconsistent with any provisions of the AFDA, the CMA, or the CMAA: AFDA, s 101K(2). The precise scope of the phrase "general supervision" is unclear but it seems unlikely the Solicitor-General could or would direct the DMP in respect to a particular case or class of cases. The Solicitor-General is also required to act in an independent and impartial manner. 
act under the general supervision of the Solicitor-General in the same manner and to the same extent as a

Crown Solicitor.

Through this mechanism, the Solicitor-General is responsible to Parliament (and ultimately to the public) for the overall work of the DMP, and hence for the overall prosecution system within the Defence Force.

\section{F The Court Martial Trial}

In 2009 the system of courts martial in New Zealand underwent significant reforms with the jettisoning of a number of old procedures and the introduction of more modern approaches based on civilian trial and appeal practices. ${ }^{42}$

When the Court Martial sits to conduct a trial, it sits as a division of one judge. ${ }^{43}$ A Court Martial consists of a presiding judge, along with a number of military officers as "members" to act as fact finders. The number of fact finders depends upon the rank of the accused and the seriousness of the offence. ${ }^{44}$ For serious offences, five military members must be appointed and, in other cases, three military members are appointed. In a civilian trial, the jury is usually 12 members although the Court can, in prescribed circumstances, sit with fewer than 10 members. ${ }^{45}$ Unlike civilian trials, the accused cannot "opt in" or "opt out" of a jury trial: judge-alone trials are not recognised.

Section 24(e) of the NZBORA specifically excludes the right to a trial by jury for "an offence under military law tried before a military tribunal". The military members in a Court Martial are thus

42 Armed Forces Law Reform Bill. Some of the old procedures which have been abandoned included: a majority vote for a finding of guilt or innocence (AFDA, s 133); and the power of the court to suspend a range of sentences (AFDA, s 138). A key driver of these reforms was the enactment of the New Zealand Bill of Rights Act 1990 (NZBORA).

43 CMA, s 9(1).

44 If the accused is an officer and the offence is a "serious offence", then five military members are appointed and if not, three military officers are appointed: CMA, s 24. A serious offence means an offence which carries a maximum sentence of life imprisonment or a term of imprisonment of 20 years or more: CMA, s 21(1)(b). Where the accused is a rating, soldier, or airman, the Registrar may assign, if the proceedings relate to a serious offence, five officers, or four officers and a warrant officer, or three officers and two warrant officers: CMA, s 24(2). In any other case the Registrar may assign three officers or two officers and one warrant officer: CMA, s 24(2)(b). It is preferable if the rank of the military members reflects the rank of the accused and the seriousness of the offence: CMA, s 24(3). For the constitution of courts martial prior to the 1950s see "CourtsMartial" [1941] NZLJ 25.

45 Juries Act 1981, s 22(1)(a). The Juries Act does not state a minimum number of jurors. 
not equivalent to a civilian jury. A Court Martial is a sui generis legal institution, discussed below. ${ }^{46}$ A civilian jury is simply not suited for a Court Martial: ${ }^{47}$

The different nature of the judges of fact in a military trial as compared with a civilian trial is grounded in the different underlying philosophy of military justice and the practical requirements of military operations. The goal of the military justice system is the maintenance of discipline in the armed forces. This is a command responsibility. It therefore calls for the exercise of judgment by officers who are trained and experienced in the exercise of command and its concomitant duty to maintain discipline.

The role of the military members is one of the most significant and fundamental differences between the court martial and a civilian trial. ${ }^{48}$

The requirement that the fact finders be independent is reinforced by a number of provisions in the CMA. Section 23 of the Act sets out the circumstances where a military member is disqualified from sitting. ${ }^{49}$ Further, similar to a civilian jury, the accused can object to the appointment of specific members, but only on the basis that the proposed member may not be impartial or is not qualified to sit. ${ }^{50}$ This is a far more limited right to challenge compared to a civilian jury where the accused (and the prosecution) can challenge four jurors without cause, ${ }^{51}$ and can challenge an unlimited number of potential jurors for cause (i.e. the person is not impartial or is unable to act effectively). ${ }^{52}$

One of the reforms introduced by s 28 of the Military Justice Legislation Amendment Act was to give the prosecutor a right to object to the appointment of a military member.

The military members can ask questions during the proceedings to clarify any matters, including questioning the accused if he or she gives evidence. ${ }^{53}$ This is a more expansive right than the

46 Griggs, above n 9, at 306; and $R$ v Sargison (1972) 1 NZCMAR 51 (CMAC) at 55.

47 Griggs, above n 9, at 306.

$48 R v$ Sargison, above $\mathrm{n} 46$. In the civilian system the role of the jury has long been considered vital, not just to achieve a fair trial, but more broadly, a key mechanism constituting a free and democratic society: see for example Patrick Devlin Trial by Jury (revised ed, Stevens \& Sons, London, 1965).

49 These include where the officer was (a) the commanding officer of the accused between the date of charge and the trial; (b) the prosecutor or a witness; or (c) has investigated the charge. By comparison, under s 7 of the Juries Act, a person is disqualified from sitting as a juror if he or she has (at any time) been sentenced to imprisonment for life; or for a term of three years or more; or (within the last three months) to home detention of more than three months.

50 CMA, s 27(1); and Armed Forces Discipline Rules of Procedure, r 63(2). Under s 25(a) of the NZBORA an accused has a right to a fair and public hearing by an independent and impartial court. This includes an independent and impartial jury.

51 Juries Act, s 24

52 Juries Act s 25

53 Armed Forces Discipline Regulations, r 103(1)(b). 
analogous right of civilian jurors who can only ask a question through the trial judge who can reformulate the question or simply prohibit the question being asked. ${ }^{54}$

As with a civilian trial, the Court Martial must sit in open court, in the presence of the accused, and can sit in any place in New Zealand, or indeed, the world. ${ }^{55}$ To this extent the CMA has extraterritorial jurisdiction, as does the AFDA. ${ }^{56}$ The Judge can, however, order the Court to be closed in specified circumstances, ${ }^{57}$ and the accused can be removed in specified circumstances. ${ }^{58}$ The accused can be represented by a lawyer or by a defender. ${ }^{59}$

The Judge can rule on any question of law that arises during or before the trial. ${ }^{60}$ The Judge can also rule on a question of law before the military members are appointed. ${ }^{61}$ The range of questions of law that the Judge can rule on is very extensive and includes the admissibility of evidence, a submission of no case to answer, severance of trials and the fitness of the accused to stand trial. ${ }^{62}$

54 Evidence Act 2006, s 101.

55 CMA, s 37(1). In criminal proceedings the general principle is that the court is open to the public: Criminal Procedure Act, s 196(1). The defendant has a right to be present at all hearings but the court has power to exclude the defendant if he or she becomes disruptive: Criminal Procedure Act, s 117.

56 As stated above, the provisions of the AFDA can apply to persons outside New Zealand. Section 4 states "[t]his Act applies to all acts done or omitted whether in New Zealand or elsewhere." See also Armed Forces Discipline Rules of Procedure, r 5(b)(c). Civilian courts generally exercise criminal jurisdiction in respect to offences committed within New Zealand but if a statute permits, a court can exercise jurisdiction in respect to an act (or omission) which has occurred outside of New Zealand: see for example Walsh $v R$ [2007] 2 NZLR 109 (SC); and the Crimes Act, s 8.

57 For example, the court is closed whilst the judge sits alone to determine a question of law, or the military members deliberate (CMA, s 38(1)). Under ss 39-43 of the CMA the judge can limit the scope of open court.

58 CMA, s 37(2). A defendant in civilian proceedings can also be removed if he or she disrupts the proceedings: Criminal Procedure Act, s 117(2).

59 CMA, s 68. A "defender" is a member of the Armed Forces who undertakes the defence of the accused: Armed Forces Discipline Rules of Procedure, r 3. See Armed Forces Discipline Rules of Procedure, r 69-70 (rights of counsel); r 64-65 (access to legal representation); and r 15(1)(e) (legal aid). Payment of legal fees is made pursuant to pt 2 of the Armed Forces Discipline Regulations. In civilian proceedings the defendant has a right to a fair trial and the trial could be unfair if the defendant lacked legal representation: $R v$ Condon [2006] NZSC 62, [2007] 1 NZLR 300. NZBORA, s 24(c)(f) recognises a right of persons charged to consult and instruct a lawyer, but does not recognise a right to a lawyer at trial at public expense: $R v$ Condon; and Fahey $v R$ [2017] NZCA 596, [2018] 2 NZLR 392.

60 CMA, s 44(1). See Armed Forces Discipline Rules of Procedure, r 74 (military members not permitted to see the ruling).

61 CMA, s 44(2)

62 CMA, s 44(4) 
These are the same powers that a civilian judge possesses. ${ }^{63}$ Arguably, where a Court Martial Judge determines a question of law prior to the appointment of the military members, this is analogous to a "pre-trial" ruling recognised in the Criminal Procedure Act. ${ }^{64}$

The decision of the Court Martial Judge (or a civilian judge in the civilian context) to admit crucial prosecution evidence may well persuade the accused to plead guilty. Conversely, the decision to exclude crucial prosecution evidence may well persuade the prosecution to abandon the prosecution.

A party to the proceedings can appeal any of these rulings. ${ }^{65}$ This is a particularly important right for the prosecution because it enables them to challenge on appeal a ruling which could otherwise terminate the prosecution case (terminatory rulings). If the prosecution is successful on the appeal then the trial will resume in the normal way, whereas in the absence of such an appeal right, the prosecution would (or could) fail.

The Court Martial Judge can call or recall any witness that he or she considers should be questioned on any matter that the Judge thinks requires clarification. ${ }^{66}$ This is not a feature of the civil criminal trial but is found in European "inquisitorial" systems. Clearly, this gives the Judge, rather than the parties, significant power over the course of the trial.

Identical to a civilian trial, at the conclusion of the prosecution case, the Judge can rule on a no case submission. ${ }^{67}$ At the conclusion of the whole case the Judge sums up the evidence and directs the members on the applicable law. ${ }^{68}$

\section{G Rules of Procedure}

The Criminal Procedure Act does not apply to proceedings under the AFDA (except as expressly provided) nor to proceedings on appeal from decisions under the Act. ${ }^{69}$ The only part of the Criminal

63 Under various provisions of the Criminal Procedure Act, the judge can rule on questions of law e.g. ss 78, 79, 80, 101 and 109. Sections 215 and 217 of the Act set out the range of pre-trial rulings that can be appealed, with leave.

64 Criminal Procedure Act, ss 215 and 217.

65 CMAA, s 7.

66 CMA, ss 29(4) and 45.

67 Armed Forces Discipline Rules of Procedure, rr 101-102.

68 Armed Forces Discipline Rules of Procedure, r 107.

69 Criminal Procedure Act, s 7(2). It is not surprising that the Criminal Procedure Act does not apply to the military system as the Act is premised on prosecutions being conducted by Crown Solicitors, and in specific civilian courts. Further, appeals from those civilian courts are to other civilian courts pursuant to a complex arrangement of appeal paths. 
Procedure Act that explicitly applies to trials in the Court Martial is sub-pt 3 of pt 5, which refers to public access to court proceedings and restrictions on publishing. ${ }^{70}$

The Criminal Procedure (Mentally Impaired Persons) Act 2003 also "does not apply to proceedings under the Armed Forces Discipline Act 1971, or to proceedings on appeal from any decision under that Act". ${ }^{71}$ Nevertheless, under the AFDA the Court has the same jurisdiction as prescribed in the Criminal Procedure (Mentally Impaired Persons) Act to determine that a defendant is not fit to stand trial, or was insane at the time of the offence. ${ }^{72}$ The same type of procedures contained in the Criminal Procedure (Mentally Impaired Persons) Act will apply in the Court Martial.

The Military Justice Legislation Amendment Act introduced a new s 187A into pt 10 of the AFDA (effective from 30 November 2018) whereby the Court Martial must act through the Judge alone in dealing with mentally impaired persons, including determining fitness to plead.

The Bail Act 2000 does not directly apply although some provisions in that Act may be relevant. ${ }^{73}$ Similarly, the Criminal Disclosure Act 2008 does not apply to Court Martial proceedings. ${ }^{74}$

\section{H Rules of Evidence}

The Evidence Act does not itself state whether it applies to proceedings in the Court Martial. However, importantly, s 71(1) of the CMA states:

The rules of evidence that apply in the High Court for criminal proceedings (including the rules of evidence contained in the Evidence Act 2006 and in any other enactment containing any rule of evidence) are the rules of evidence to be followed in proceedings of the Court Martial.

Section 71(1) is important because, in general, it gives the accused the same rights as applicable in a civilian court in respect of key issues such as the admissibility of evidence and warnings to the factfinders. The privilege against self-incrimination also applies. However, ss 72-74 of the CMA limit the general application of rules of evidence in respect to matters that pertain specifically to the military. ${ }^{75}$

70 AFDA, s 145

71 Criminal Procedure (Mentally Impaired Persons) Act 2003, s 5(2).

72 AFDA, pt 10, ss 187-198.

73 For example, under s 49(4)(a) of the CMA some provisions of the Bail Act must be taken into account (eg s 8(1)(3)) and under s 50(4)(b) of the CMA), other provisions in the Bail Act may be taken into account (eg ss $8(2)$ and $14(3))$.

74 Criminal Disclosure Act, s 6.

75 That is, ss 72-74 sets out various rules which permit proof of certain acts through the use of specified documents (eg attestation papers, letters from commanding officers, entry into military records and certificates). 
It therefore appears clear that the provisions of the Evidence Act will apply to proceedings in the Court Martial, unless exempted or modified by the CMA. ${ }^{76}$ Specifically, the provisions of the Evidence Act that relate to a jury trial can apply (to the extent they are applicable and can be modified) to proceedings of the Court Martial that involve military members. ${ }^{77}$ This is an important provision as it gives the accused the same benefits as a civilian accused, in terms of mandatory jury warnings, the requirements of identification evidence, and the like (however, as stated above, the Court Martial is not in fact equated to a jury trial).

\section{Findings}

A finding of guilt or innocence must be the unanimous decision of the military members. ${ }^{78}$ If the military members are unable to arrive at a unanimous finding the Judge must discharge the jury ${ }^{79}$ and refer the charge back to the DMP. ${ }^{80}$ By comparison, in civilian trials, a majority verdict is permitted if the jury have deliberated for at least four hours. ${ }^{81}$

The military members must obey any ruling by the Court Martial Judge on a question of law. ${ }^{82}$ If the military members declare a finding of guilty and "the judge is of the opinion that the finding is contrary to law", then the Judge must "advise the military members once (but only once) more of the

76 Section 71(1); and Armed Forces Discipline Rules of Procedure, r 15(1)(h). Chapter 6 of the Manual of Armed Forces Law Volume 1: Commander's Handbook on Military Law, above n 11, sets out the rules of evidence which apply in summary proceedings. The ordinary rules of evidence do not apply in summary proceedings: Armed Forces Discipline Rules of Procedure, r 15(i).

77 Under s 70(2) of the CMA the provisions of the Evidence Act which do apply include: s 32(2)(b) (no inference from pre-trial silence); s 45(3)(e) (record of visual identification parade); s 45(3)(f) (recording of pictorial identification); s 76 (prohibition on giving evidence of deliberations of jury); s 83(1) (ordinary manner of giving evidence); s 98(5)(a) (further evidence after close of case); s 105(1)(b) alternative ways of giving evidence); s 109(2) (giving evidence by undercover police officer); s 121(2) (unnecessary to warn jury of dangers of corroboration); and s 122-127 (warnings regarding unreliable evidence, ways of offering evidence, evidence of lies, evidence of children and delay). Other provisions of the Evidence Act could apply if they "relate to a trial before a jury" (s 70(1)).

78 CMA, ss 55(1) and 48(1). The judge does not participate in the determination of guilt or innocence: see Armed Forces Discipline Rules of Procedure, r 108.

79 CMA, s 48(1). The Act does not specify any period that must elapse before the judge can discharge the members.

80 CMA, s 55(2).

81 Juries Act, s 29C. A majority verdict means, where the jury consists of a certain number, a verdict agreed to by all except one juror. A majority verdict could thus be $11 / 12$ or $10 / 11$ or $9 / 10$.

82 CMA, s 44(3). 
findings that are, in the judge's opinion, open to them in law". ${ }^{83}$ This means that even if the Judge concludes that the finding of guilt represents an error, he or she cannot take any further action. By comparison, in a civilian trial, the Judge can dismiss a charge if the Judge is satisfied that, as a matter of law, a properly directed jury could not reasonably convict the accused. ${ }^{84}$ In this situation, the alleged error by the military members could be challenged on appeal, as discussed below. ${ }^{85}$

\section{J Sentencing}

The Sentencing Act does not, in general, apply to proceedings under the AFDA, nor to appeals under the Act (except where otherwise stated). ${ }^{86}$ The only provisions of the Sentencing Act that explicitly apply to proceedings in the Court Martial and to appeals from the Court are s 6 (penal enactments not to have retrospective effect to the disadvantage of the offender) and ss 102-114 (sentencing for murder).

In general, the CMA and the AFDA contain the key principles and laws regarding sentencing of persons found guilty following a Court Martial. The only available sentences are those set out in sch 2 of the AFDA. ${ }^{87}$ Two of these sentences are available under the Sentencing Act (imprisonment and fine) but the remainder are limited to military offences. The AFDA also contains sub-rules regarding the imposition of particular sentences. ${ }^{88}$ For example, if an officer is sentenced to a term of

83 CMA, s 30(2)(h). However, at the close of the prosecution case, the Judge can rule on a "no case" submission: see $\mathrm{r} 102$ of the Armed Forces Discipline Rules of Procedure. See also Smith $v R$ (1977) 1 NZCMAR 60 (CMAC).

84 Criminal Procedure Act, s 147(4)(c). Prior to the Criminal Procedure Act, s 347(3) of the Crimes Act enabled a judge to direct the jury to discharge the accused. Section 347 has since been repealed and replaced by s 147 .

85 That is, by arguing that the decision is "unreasonable or cannot be supported having regard to the evidence": CMAA, s 9A.

86 Sentencing Act 2002, s 5(2) states "[t]his Act does not apply to proceedings under the Armed Forces Discipline Act 1971, or to proceedings on appeal from any decision under that Act, except as expressly provided in that Act." However, s 63(1)(c) of the CMA refers to s 10(1)(b)(d) and (e) of the Sentencing Act.

87 These are imprisonment, dismissal, detention, reduction in rank, forfeiture of seniority, stay of seniority, fine, severe reprimand and a reprimand. The court can also order payments for compensation or restitution: AFDA, ss 86-87. Punishments for summary matters are limited to sch 2 of the Armed Forces Discipline Rules, $r$ 15(1)(f). The Armed Forces Discipline Regulations also sets out rules regarding punishments: pt 1.

88 For example, if a person is liable on conviction to a sentence of life imprisonment or for any other term, the court may impose a shorter term which, in the case of a person liable to life imprisonment, shall not exceed 14 years or to one or more of the less severe punishments in sch 2 (s 80). Further, no officer can be sentenced to detention (s 80(2)). 
imprisonment, then he or she is deemed to be dismissed from Her Majesty's Service. ${ }^{89}$ Another example is that the maximum period of detention is two years. ${ }^{90}$

The sentence of the Court is decided by a majority decision of the military members and the Judge voting together. ${ }^{91}$ If the votes are equal, the Judge has the casting vote. ${ }^{92}$ This is another significant difference between the military system and the civilian system. In the civilian system, once the fact finders (jury) have completed their role, they return home and have no further involvement in the proceedings. Sentencing is purely a matter for the Judge. Having the fact finders (military members) decide on the sentence is again, a feature of the inquisitorial system. This role of the military members reflects a properly grounded sentiment that military members are acutely aware of the distinct consequences of the various "military" sentences that can be imposed, whereas this does not apply in the civilian context. ${ }^{93}$

Crucially, when sentencing, the Court is required to take into account any applicable sentencing guideline, issued by the Armed Forces Discipline Committee (the Discipline Committee) ${ }^{94}$ The Discipline Committee consists of the Chief of Defence Force, Vice-Chief of Defence Force, Chief of Navy, Chief of Army, Chief of Air Force, Commander Joint Forces New Zealand, the Judge Advocate General, the DMP and a representative of the Armed Forces Defence Counsel Panel. ${ }^{95}$ One of the functions of the Discipline Committee is to produce guidelines in respect of sentencing principles, sentencing levels, particular types of sentences, other matters relating to sentences, grounds for departing from the guidelines and any incidental functions. ${ }^{96}$

In performing its functions, the Discipline Committee must ensure that any guidelines it produces are, to the extent that it is applicable, consistent with the Sentencing Act. ${ }^{97}$ Through this type of mechanism, the military justice system has adapted features of the civilian system.

89 Section 82(1).

90 Section 83. Military members are able to utilise their collective knowledge of service discipline and facts relating to day-to-day activities and customs of the Armed Forces: $R v$ Main (1962) 1 NZCMAR 30 (CMAC) at 31 .

91 CMA, s 61(1); and Armed Forces Discipline Regulations, r 118.

92 CMA, s61(2).

93 Griggs notes that the requirement for discipline in the armed forces is critical and the military members bring with them experience in the exercise of judgment by officers: Griggs, above n 9, at 291-301. Discipline is a key aspect of military sentencing.

94 CMA, s 65.

95 AFDA, s 160.

96 AFDA, s 161.

97 AFDA, s 162(2). 
The role of the Discipline Committee is analogous to the role of the Court of Appeal in producing sentencing guidelines for the civilian courts. ${ }^{98}$ Just as Court of Appeal Judges are considered experts in determining appropriate sentences for civilian offences, members of the Discipline Committee are considered to have expertise in determining sentences for military offences. In both cases, the guidelines enhance consistency in sentencing, which is a most laudable goal.

The Court Martial can only impose one sentence, even where there are multiple offences charged. ${ }^{99}$ This avoids the complexities that can arise in the civilian system from orders for concurrency and cumulation. By comparison, a civilian court can impose multiple sentences for multiple offences. ${ }^{100}$

Further, the Court Martial does not set a non-parole period or minimum term if a sentence of imprisonment is imposed. This is not surprising because if a non-parole period were set, the military justice system would have to have a system of parole in place, with associated parole officers and the like. Not setting a minimum term may appear potentially unfair in that the prisoner would, prima facie, be required to serve the full term imposed. However, a mechanism is in place to permit a prisoner to be released before the expiry of the full sentence of imprisonment. This is the key role of the Reconsidering Authority, as discussed below. (Instead of passing a sentence, the Court has a discretion to order the offender to appear for sentence if called upon, within a nominated period, not to exceed one year.) $)^{101}$

\section{K The Reconsidering Authority}

Section 151(1) of the AFDA establishes a Reconsidering Authority. The idea of such a body is not new. Three types of reconsidering authorities were provided for in $1971 .{ }^{102}$ The Authority consists of a judge appointed by the Chief Judge and two or more superior commanders appointed by the Judge Advocate. ${ }^{103}$ The functions of the Authority are to "reconsider every sentence of imprisonment or

98 Guidelines produced by the Court of Appeal are not pursuant to statutory provisions but rather pursuant to the inherent powers and role of the Court of Appeal in the performance of its function of determining criminal appeals. For a detailed discussion of the development of guideline judgments by the Court of Appeal see $R v$ AM [2010] NZCA 114, [2010] 2 NZLR 750.

99 AFDA, s 79.

100 Within the constraints of the principle of totality: see Sentencing Act, s 85(2); and Robson $v R$ [2015] NZCA 609.

101 CMA, s 62. If the offender is subsequently convicted of further offences, then the DMP can apply to have the offender brought before the Court to be dealt with for the original offence. In the civilian system, under the Sentencing Act, s 11, an offender can be discharged or called upon to come up for sentence at a future date.

102 AFDA, s 166. In 1971, the reconsidering authorities could be a board of officers, or an officer appointed by the Chief of Staff. The purpose of the authority was to reconsider sentences of imprisonment and detention passed by a Court Martial, but only after the sentence had been reviewed by a "reviewing authority".

103 AFDA, s 151(2). 
detention imposed by the Court Martial that is for a term of 6 months or more". ${ }^{104}$ The Authority "may" reconsider any other sentence imposed by the Court Martial. The Authority must reconsider each sentence of imprisonment or detention at least once every six months while the sentence is being served. ${ }^{105}$ Clearly, this function of the Authority does not involve any appeal.

In addition, a service prisoner can lodge a petition against his or her sentence with the Authority. ${ }^{106}$ The Authority must consider every petition it receives. If the Authority remits all or part of a sentence, it must not make a decision that results in a more severe sentence than that imposed before the remission. ${ }^{107}$

The Military Justice Legislation Amendment Act introduced new rights for crime victims. The Reconsidering Authority must advise the victim of reconsideration (new s 155(1A)), the victim can make submissions to the Authority (new s 155(1B)), if a hearing is to be held the Authority must advise the DMP and the victim (new s 155(3), the victim is entitled to appear and make submissions (new s 155(3A)) and a new set of victims' rights is provided in new pt 10A (ss 198A-198O).

\section{Early Release}

As stated above, the Parole Act 2002 does not apply to sentences within the military, and the Court Martial does not set a "non-parole" period or a "minimum term". It is therefore important for the military to have some system in place whereby the sentence imposed can be reviewed by a nonjudicial body, in order to determine when the prisoner might be released prior to the expiry of the full sentence imposed by the Court Martial. ${ }^{108}$

If the Authority is to reconsider a sentence or detention, it must give the prisoner 14 days' notice and the prisoner may request a hearing before the Authority and be legally represented. ${ }^{109}$ If the prisoner requests a hearing, then the DMP must be notified and he or she may attend the hearing. ${ }^{110}$ If the prisoner does not request a hearing, the reconsideration of the sentence or detention takes place "on the papers". ${ }^{111}$

\footnotetext{
104 AFDA, s 152(1)(a).

105 AFDA, s 152.

106 AFDA, ss 152-153; and pt 5 of Armed Forces Discipline Regulations, ss 141-142 (form 7 is used).

107 AFDA, s 154(2).

108 If a court does not set a minimum term, then either a statute can prescribe a minimum term or, a non-judicial body can be empowered to determine the early release of a prisoner.

109 AFDA, ss 152 and 155(1).

110 AFDA, ss 152 and 155(3).

111 This is similar to the power of the Court of Appeal to determine a sentence appeal on the papers: Criminal Procedure Act, s 329 and Court of Appeal (Criminal) Rules, r 23. Also similar to the power of a civilian court
} 
The Authority may call for any written reports, and can hear evidence if a hearing is held. ${ }^{112}$ These reports and evidence concern the circumstances of the prisoner. The Authority may remit the whole or part of the sentence that remains to be served, on the grounds of:

(a) good conduct of the prisoner or detainee during the term of the sentence;

(b) compassionate grounds; or

(c) any other grounds. ${ }^{113}$

The term "remit" here does not mean the sentence is sent back to the sentencing court but rather, that the remitted part of the sentence is waived and does not need to served.

The sentence imposed by the Court Martial is unaffected and remains on the military records. The early release of a prisoner pursuant to an order for remission by the Reconsidering Authority is analogous to the automatic setting of a minimum term pursuant to s 84(1) of the Parole Act (for sentences of 24 months or more). ${ }^{114}$

In determining release in the civilian parole system, one of the key considerations is the behaviour of the prisoner whilst in custody and any significant changes in the general circumstances of the prisoner. This equally applies in the military system.

The right of a prisoner to petition the Authority is a form of appeal, although a right to petition is different from a statutory right to appeal or apply for leave to appeal.

In summary, it can be seen that the modern Court Martial is sui generis, sharing some features of civilian appeal courts but also having distinct features of its own. Despite the appearance of rigid adherence to codes of discipline, the military justice system has a number of "safety nets" to temper what otherwise could be harsh consequences.

\section{PART II: APPEALS FROM THE COURT MARTIAL}

All of the key decisions made in the Court Martial can be appealed. Unlike the civilian appellate jurisdiction, the court martial system does not have a system of discrete "appeal paths". Instead, the first appeal court is the Court Martial Appeal Court (CMAC). Subsequent applications for leave to

to consider "on the papers" an application for a retrial or a rehearing under the Criminal Procedure Act, ss 125 and 177: see s 125(6).

112 AFDA, s 156. Similar to the function and role of the Parole Board, except the sentencing court determines the non-parole period.

113 AFDA, s 158

114 Under s 84(1) of the Parole Act, a non-parole period of one third the sentence will apply for a long term determinate sentence if the Court has not set a minimum term. A long term determinate sentence is a sentence of 24 months or more. Under s 86(1) of the Parole Act, the statutory release date for a short term determinate sentence is the date the prisoner has served one half of the sentence. The sentencing Court is empowered to override these statutory minimum periods if the Court thinks fit. 
appeal a decision of the CMAC can be made to either the Court of Appeal or the Supreme Court. The same strict statutory pre-requisites for an application for leave to appeal to the Court of Appeal or the Supreme Court apply to appeals from decisions of the CMAC as they do to appeals in the civilian system. The right to appeal a decision of the Court Martial is not found in the CMA but rather in the CMAA.

\section{A The Court Martial Appeal Court (CMAC)}

The CMAC of New Zealand was established pursuant to s 3(1) of the CMAA. In 1953 the CMAC (then known as the Courts-Martial Appeal Court) was established, some eight years after persons convicted in the civilian criminal courts were given a statutory right to appeal convictions and sentences from proceedings upon indictment. ${ }^{115}$ The CMAA was based upon, and is almost identical to, the Courts-Martial (Appeals) Act 1951 (UK).The English Act was preceded by a plethora of governmental committees of inquiry and other reports as to whether such an appellate body was required. ${ }^{116}$

The Judges of the CMAC are Judges of the High Court; and such other persons being barristers of the High Court (who have held a practising certificate for at least seven years) or former Judges of the High Court. ${ }^{117}$ The CMAC is an independent civilian court, although clearly an integral component of the overall military appellate justice system.

For the purpose of hearing and determining appeals, the CMAC is "summoned in accordance with directions given by the Chief High Court Judge" and is duly constituted if the Court consists of an uneven number of judges, not being less than three, and at least one of the judges is a High Court Judge and one is an appointed judge. ${ }^{118}$

\section{B Jurisdiction}

The following decisions made by a Judge of the Court Martial can be appealed or be the subject of an application for leave:

(a) a bail decision;

(b) a ruling on a question of law;

115 Criminal Appeal Act 1945. Although various forms of civilian appeal against conviction and sentence were available prior to 1945, the Criminal Appeal Act permitted, for the first time, an appeal based on error of fact, error of law, or a combination of both, from proceedings on indictment. In 1991, the requirement of leave for a conviction and sentence appeal was removed by the Crimes Amendment Act 1991.

116 The committees of inquiry began in 1919 with the Darling Committee reviewing Court-Martials in the Army and Navy, followed by the Oliver Committee in 1938, the Lewis Committee in 1946, the Pilcher Committee in 1949 and the Napier Committee in 1950: see Hook, above n 20, at 46-48.

117 CMAA, s 3(1)(b).

118 CMAA, s 4(1). 
(c) a conviction and sentence;

(d) an acquittal based on a finding of insanity; and

(e) a finding of unfitness to stand trial.

In addition, the Judge Advocate General and the Minister of Defence can refer a "finding" or other decision to the CMAC, as discussed below. ${ }^{119}$

These appeal rights essentially mirror those recognised in the civilian justice system. ${ }^{120}$ For the purposes of this article, the right to appeal a conviction, sentence and a ruling will be discussed, comparing and contrasting the civilian equivalent rights.

\section{Conviction Appeal}

Section 9(1) of the CMAA provides for a right to appeal a conviction. ${ }^{121}$ The appeal is of right; leave is not required. This is in accordance with s 25(h) of the NZBORA. A person who pleaded guilty can appeal the conviction. ${ }^{122}$

Section 9A of the CMAA provides:

(1) On an appeal to the court against conviction, the court must-

(a) allow the appeal if it considers that-

(i) the finding of the Court Martial should be set aside on the ground that it is unreasonable or cannot be supported having regard to the evidence; or

(ii) the finding of the Court Martial involves a wrong decision on a question of law; or

(iii) there was, on any ground, a miscarriage of justice; or

(iv) the trial was a nullity; or

(b) dismiss the appeal in any other case.

(2) However, the court may dismiss the appeal if it considers that no substantial miscarriage of justice has actually occurred even though it considers that the point raised in the appeal might be decided in favour of the appellant.

119 CMAA, s 24.

120 When the Court Martial Appeal Court (CMAC) was first established in 1953, only a right to apply for leave to appeal a conviction was recognised. In 1959, an amendment to the CMAA permitted an appeal against a conviction as of right where the sentence exceeded 90 days. An appeal against a sentence was not recognised.

121 The equivalent civilian right is in s 229(1) of the Criminal Procedure Act. Under s 229(1), leave is not required.

122 Although s 9 of the CMAA does not provide that a person who pleaded guilty can appeal a conviction, it is clear from civilian law that such a right exists (Criminal Procedure Act s 232(5)). However, an appeal court would only permit an appeal where the circumstances are exceptional. See for example Abraham $v$ District Court at Auckland [2007] NZCA 598, [2008] 2 NZLR 352; and $R v$ Merrilees [2009] NZCA 59 at [4]. Where the defendant has pleaded guilty, the ground of appeal will be that a miscarriage of justice has occurred. 
Section 9A of the CMAA is different from its civilian counterpart in s 232 of the Criminal Procedure Act. Section 9A is based on s 385(1) of the Crimes Act, which in turn was based on the original "common form" appeal provisions in the Criminal Appeal Act 1945, s 4(1). In particular, s 9A(2) retains the "proviso" which has been jettisoned in s 232 of the Criminal Procedure Act.

The ground that the finding is "unreasonable or cannot be supported having regard to the evidence" is analogous to the similar ground in s 232(2)(a) of the Criminal Procedure Act. ${ }^{123}$ The focus here is on the elements of the particular offence, and an assessment of the facts (or assessing what the fact finders accepted as "facts") by the appeal court. ${ }^{124}$

The ground that the finding involves a "wrong decision on a question of law" is not found in s 232 of the Criminal Procedure Act. ${ }^{125}$ The focus is on legal error by the Judge presiding at the Court Martial. It is, however, insufficient simply to establish legal error; the error must be related to the eventual finding of the court.

The ground of "a miscarriage of justice" in s 9A of the CMAA is the broadest of all the grounds and can encompass any of the ways in which a serious error or mistake has occurred in the trial or in relation to the trial. This ground is analogous to s 232(2)(c) of the Criminal Procedure Act, and the case law concerning the meaning of s 232(c) of the Criminal Procedure Act guides the CMCA. ${ }^{126}$ Examples here include incompetence of trial counsel, judicial bias, irregularity concerning the fact finders, or lack of legal representation.

The ground that the trial was a nullity is analogous to s 232(4)(b) of the Criminal Procedure Act. It will be rare for this ground to be upheld. ${ }^{127}$

123 Section 232(2)(a) of the Criminal Procedure Act has abandoned the term "cannot be supported having regard to the evidence" because it is superfluous and adds unnecessary complexity: see Owen $v R$ [2007] NZSC 102, [2008] 2 NZLR 37 at [12].

124 See for example Jameson $v$ R (1994) 1 NZCMAR 195 (CMAC), where the Court held the facts did not disclose the offence. Where the finding is challenged on the basis of the fact finders' assessment of the credibility of witnesses, then an appeal court will be very reluctant to intervene.

125 A wrong decision on a question of law would come within the broader definition of a miscarriage of justice in s 232(4) of the Criminal Procedure Act.

126 A "miscarriage of justice" is defined in s 232(4) of the Criminal Procedure Act as meaning:

... any error, irregularity, or occurrence in or in relation to or affecting the trial that- (a) has created a real risk that the outcome of the trial was affected; or (b) has resulted in an unfair trial or a trial that was a nullity.

There are an unlimited number of circumstances that could constitute a miscarriage of justice.

127 Wiley $v R$ [2016] NZCA 28, [2016] 3 NZLR 1 at [33]. This could include where the charge is not known at law, or the charge is heard in the wrong court. The Criminal Procedure Act includes trial nullity as part of the 
The most significant difference between s 9A of the CMAA and s 232 of the Criminal Procedure Act is the retention of what has become known as "the proviso" in the former. The effect of the proviso in s $9 \mathrm{~A}(2)$ is that the CMAC can dismiss an appeal even if it is satisfied that a miscarriage of justice occurred, so long as the miscarriage of justice was not a "substantial" miscarriage of justice. ${ }^{128}$ If the appellant can demonstrate an error was made, then it is up to the prosecution (respondent) to persuade the appeal court that despite the error, no substantial miscarriage of justice in fact occurred. Not surprisingly, the proviso has been abandoned in the Criminal Procedure Act and in other commonwealth jurisdictions. Arguably, s 9A should also be reformed by jettisoning the proviso.

The available orders on a successful conviction appeal are set out in s 9A(3) of the CMAA. The Court: ${ }^{129}$

(a) may quash the conviction; and

(b) may do any of the following:

(i) direct a judgment and finding of acquittal to be entered; or

(ii) direct a new trial; or

(iii) make any other order that justice requires.

These are essentially the same orders available to a civilian appeal court. ${ }^{130}$

\section{Sentence Appeal}

Pursuant to s 9(1)(b) of the CMAA, a person convicted can appeal the sentence imposed (unless the sentence is one fixed by law). The same right is found in s 244(1) of the Criminal Procedure Act. The DMP can also appeal the sentence. ${ }^{131}$ For civilian cases, this prosecution right is also found in $\mathrm{s}$ 246(1) of the Criminal Procedure Act.

Prior to 2009, a sentence appeal was not available for the convicted service person and the prosecution had no appeal rights at all. Thus, the right to appeal sentence (without leave) has significantly aligned the military provisions with the civilian counterpart.

definition of a miscarriage of justice, whilst the CMAA recognises it as a distinct ground of appeal separate from the miscarriage of justice ground.

128 Therefore the CMAC will have to grapple with the distinction between a "miscarriage of justice" in s 9A(1)(iii) and a "substantial miscarriage of justice" in s 9A(2). The Court may be guided by cases such as Matenga $v R$ [2009] NZSC 18, [2009] 3 NZLR 145; and $R v$ Gwaze [2010] NZSC 52, [2010] 3 NZLR 734 at [58].

129 See also Armed Forces Discipline Regulations, rr 129-130.

130 Criminal Procedure Act, s 233.

131 CMAA, s 9(2). 


\section{E General Approach to Sentence Appeals}

As a general proposition, the CMAC follows the same approach as the Court of Appeal in civilian sentence appeals. For example, the CMAC recognises the sentencing methodology in $R v$ Taeuki ${ }^{132}$ and the principles governing a discount for a guilty plea. ${ }^{133}$

However, one notable difference is that the CMAC (and the Court Martial) will accord greater weight to previous decisions of a Court Martial than to previous decisions of a civilian appeal courts. In $R v$ Murfitt ${ }^{134}$ the CMAC stated that some guidance on this issue could be derived from the English decision of $R v$ Love where the Court stated: ${ }^{135}$

\footnotetext{
In the present class of appeal therefore it seems to us that this Court is exercising a somewhat hybrid jurisdiction and that whilst free and clearly intended by Parliament to correct any injustice which we perceive in a court-martial sentence, we must nevertheless be mindful that those imposing and confirming such sentences are, generally speaking, better placed than we are when it comes to assessing the seriousness of offending in the context of service life, and deciding upon what particular penalty is required to maintain the discipline and efficiency of the armed forces.
}

Here is an expression of the general principle that the CMAC should give significant weight to the opinion of the Judges of the Court Martial because they are more "in tune" with levels of offence seriousness and appropriate sentences for particular offences. Although the Court in $R v$ Love did not explicitly refer to the opinion of civilian judges (for the same offences), it is clear the Court was suggesting that the opinion of the Court Martial Judges should, in general, be preferred.

It is suggested that this is a significant policy position because it affects the overall doctrine of precedent (at least for sentence appeals), and shows how an appeal system develops and evolves to meet the specific needs of the parties (and institutions) involved. Moreover, the sentencing guidelines produced by the Armed Forces Disciplinary Committee must also be taken into account at sentencing.

In respect of prosecution sentence appeals, the CMAC takes a similar approach to the Court of Appeal. In $R v$ Murfitt, the CMAC stated that s 9 of the CMAA generally follows s 383 of the Crimes Act, and that the CMAC should follow the approach of the New Zealand Court of Appeal in respect

$132 R v$ Taueki [2005] NZCA 174, [2005] 3 NZLR 372, followed in $R v$ Murfitt CMAC Wellington CIV-2010485-1995, 15 December 2010 at [43]. In Hessell $v$ R [2010] NZSC 135, [2011] 1 NZLR 607 at [73] the Supreme Court confirmed that a three step process in sentencing is appropriate as it enhances transparency and accountability. In summary, the three steps are (a) determine the starting point sentence by reference to the objective circumstances of the offence; (b) adjust the starting point sentence by taking into account any mitigating or aggravating factors relating to the offender and; (c) make further adjustment for any guilty plea or assistance provided to the authorities.

133 As set out in Hessell $v R$, above $\mathrm{n}$ 132, at [14] and [22]-[23], followed in $R v$ Murfitt, above n 132, at [43].

$134 R v$ Murfitt, above n 132, at [30]; and $R v$ Love (1998) 1 CR App R 458 (CMAC).

$135 R v$ Love, above n 134, at 462, as cited in $R v$ Murfitt, above n 132, at [30]. 
of prosecution sentence appeals. ${ }^{136}$ Specifically, the Court should not increase a sentence unless persuaded the sentence is "manifestly inadequate" or the Crown can point to some error of principle in the sentence. ${ }^{137}$ Further, if an error occurred in the original sentence, and that error was caused by the prosecutor, then, on a prosecution appeal, the prosecution are not permitted to rely on that error as a ground to increase the sentence. ${ }^{138}$

\section{F Determination of Sentence Appeal}

In terms of the grounds for upholding a sentence appeal, s 9AB of the CMAA provides that the CMAC must: ${ }^{139}$

(a) do either of the following if it thinks that a different sentence should have been imposed:

(i) quash the sentence imposed and impose any other sentence warranted in law (whether more or less severe) in substitution for the sentence that was quashed; or

(ii) vary, within the limits warranted in law, the sentence or any part of it or any condition imposed in it; or

(b) dismiss the appeal in any other case.

Section 9AB is different to the civilian counterpart in s 250(2) Criminal Procedure Act because it conflates the criteria for upholding the appeal with the disposition options. Under s 9AB, the CMAC cannot impose any orders unless it is first satisfied "that a different sentence should have been imposed". In the civilian context, what this means is not simply that the appeal court might have arrived at a different sentence. Nor is it sufficient that there is any type of error. The error must be substantial or material, such as to justify quashing the sentence. ${ }^{140}$

The disposition options in s 9AB are essentially the same as in s 251 of the Criminal Procedure Act, except the CMAC has no power to remit the sentence back to the Court Martial. ${ }^{141}$

$136 R v$ Murfitt, above $\mathrm{n}$ 132, at [27].

$137 R v$ Murfitt, above $\mathrm{n}$ 132, at [27]. Prosecution appeals are not for borderline cases: $R v$ Cargill [1990] 2 NZLR 138 (CA) at 140.

$138 R v$ Murfitt, above n 132, at [52]. To do so would enable the prosecution to benefit from its own error.

139 The equivalent provision is s 251 of the Criminal Procedure Act.

140 Tutakangahau $v R$ [2014] NZCA 279, [2014] 3 NZLR 482 at [26], referring to $R v$ Shipton [2007] 2 NZLR 218 (CA) at [138].

141 This limitation reflects the practical realities that military proceedings are more "streamlined" than the civilian counterpart, and also reflects the complications associated with re-convening the original fact finders (military members), compared to a single trial judge resentencing the offender. The limitation probably also reflects the historical practice of dissolving a court martial once the proceedings were completed. 


\section{G Appeal Against a Ruling}

Prior to 2009, it was not possible to appeal a ruling made by the Court Martial Judge. However, under s 7 of the CMAA, either the accused person or the DMP can apply for leave to appeal a ruling on a question of law or procedure "that arises during proceedings in that court". This means the appeal is not brought after the proceedings have concluded. The trial must be underway, or about to get underway. It is clear that the Judge can also make such a ruling before the military members have been appointed. ${ }^{142}$

The analogous right in the civilian context is provided for in s 296 of the Criminal Procedure Act. Section 296 provides for a right to apply for leave to appeal on a question of law. The question of law must not be one that arises from a jury verdict or arose before the trial and has already been decided under sub-pt 2 of the Criminal Procedure Act. ${ }^{143}$ The question of law must arise in proceedings that "relate to or follow the determination of the charge" 144 or in the determination of the charge (e.g. including a conviction, an acquittal or the dismissal of a charge).

Section 7(5) of the CMAA provides examples of the type of rulings which can be appealed. ${ }^{145}$ These examples are not exhaustive. It is clear from s 7(5) of the CMAA that the sorts of questions of law which can be appealed relate to preliminary matters, such as jurisdiction or procedure, rather than the actual determination of the proceedings such as a conviction or acquittal. Arguably, rulings on these types of matters could constitute pre-trial rulings, particularly if the military members have not yet been appointed.

In any event, the right to appeal a ruling of the Court Martial is a significant reform because it radically expands the circumstances in which a decision of the Court Martial can be challenged. The right is particularly important for the prosecution because it enables the prosecution to salvage a potentially terminal prosecution. For example, assume the trial judge ruled that critical prosecution evidence is inadmissible. Without that evidence, the prosecution case would collapse. In the absence of a right to appeal the ruling, the prosecution case may well be terminated. With the right to challenge the ruling, if successful, the prosecution can continue. This advantage applies to all terminatory rulings" such as a ruling that there is no case to answer.

142 CMA, s 44(2).

143 Section 296(4). Appeals against pre-trial rulings are provided for separately in ss 215 and 217 of the Criminal Procedure Act.

144 In Anderson v R [2015] NZCA 518, [2016] 2 NZLR 321 the Court of Appeal held that the decision of a trial judge to refuse an application to change an election for judge-alone trial, did come within the category of "rulings" that can be appealed on a question of law. Such a ruling was held to "relate to or follow the determination of the charge".

145 For example a plea to the general jurisdiction of the court; a plea in bar of trial; an application for a separate trial; an application for severance of charges; and a submission that there is no case to answer. 
The Court Martial has the discretion to continue with the trial or to await the outcome of the application for leave to appeal. ${ }^{146}$ This is the same general procedure in civilian cases. ${ }^{147}$

Given that an appeal against a ruling of the Court Martial requires leave of the appeal court, the test and procedure for a grant of leave is important. A single Judge of the CMAC is empowered to hear and determine an application for leave to appeal a ruling under s $7 .{ }^{148}$ If the single Judge refuses to grant leave, then the applicant (either the accused person or the prosecution), upon a request to the CMAC, has a right to have the refusal reviewed by the Court as a whole. ${ }^{149}$

Analogously, in the civilian context, any two Judges of the Court of Appeal can hear and determine an application for leave to appeal. ${ }^{150}$ If the two Judges refuse to grant leave to appeal, the applicant has a right to have the application reheard by the Court of Appeal. ${ }^{151}$

In this procedural respect, the rights of military accused persons have converged with the same rights of their civilian counterpart.

The CMAA does not specify any criteria for leave to appeal. Clearly, leave will not be granted if the proposed appeal is hopeless and has no prospects at all of success. Important guidance can be obtained from Practice Note $-R v$ Leonard where the Court of Appeal sets out detailed guidance for deciding leave to appeal a pre-trial decision. ${ }^{152}$ This Practice Note provides guidance for all types of leave application.

The Court Martial Appeal Court Rules are, in effect, a replica of the Court of Appeal (Criminal) Rules 2001. The important effect of this is that the appellate procedural rights of Defence Force members are identical to their civilian counterpart, and in this respect, military law has fully aligned with civilian law.

\section{H Subsequent Appeals}

Under s 10 of the CMAA, a party to an appeal under s 6 (bail), s 7 (ruling) or s 9 (conviction or sentence) may appeal (with leave of the appeal court) to the Court of Appeal or the Supreme Court against the decision of the CMAC. In practice, the Court of Appeal is likely to be the second appeal

146 CMAA, s 8(3).

147 Criminal Procedure Act, s 222.

148 Section 25(1).

149 CMAA, s 25(2).

150 Criminal Procedure Act, s 333(1).

151 Criminal Procedure Act, s 333(3).

152 Practice Note - R v Leonard [2007] NZCA 452, [2008] 2 NZLR 218. 
court rather than the Supreme Court because of the stringency attaching to any application for leave to appeal to the Supreme Court. ${ }^{153}$

Under s 10 of the CMAA, a party to an appeal to the Court of Appeal may appeal (with leave) to the Supreme Court against a decision of the Court of Appeal. The procedure for a subsequent appeal generally follows the civilian rules for a subsequent appeal. ${ }^{154}$

\section{Special References to the CMAC}

There are two circumstances when a matter can be referred to the CMAC without being an appeal by one of the parties. The first circumstance is that the Judge Advocate General can refer "a finding made, a conviction entered, or a sentence passed in any proceedings in the Court Martial", if the Judge Advocate General thinks it is in the interests of justice or discipline to do so. ${ }^{155}$ This is a broad and general power. The power would only be exercised after all appeals by the convicted person to the CMAC have been exhausted, or, the convicted person does not wish to appeal, or perhaps the convicted person has left the Armed Forces and cannot be contacted.

The second circumstance is that the Minister of Defence may refer to the CMAC a "finding" made in the proceedings if the Minister thinks that the court should consider or reconsider that finding "because of matters that the Minister considers have not been brought to the notice of the Court Martial". ${ }^{156}$ This circumstance could include where fresh evidence has emerged (post-trial and postappeal) or where there was a failure to adduce the evidence on the initial appeal.

These two types of references must be treated as an appeal against conviction. ${ }^{157}$ Accordingly, it appears that the CMAC could not decline to deal with the reference. The purpose of these two types

153 Section 74(1) of the Senior Courts Act provides that the Supreme Court must not give leave to appeal unless the Court is satisfied "it is necessary in the interests of justice for the court to hear and determine the appeal". Section 74(2) then provides that it is necessary in the interests of justice for the Court to hear the appeal if (a) the appeal involves a matter of general or public importance; or (b) a substantial miscarriage of justice may have occurred or may occur unless the appeal is heard; or (c) the appeal involves a matter of general commercial significance. Any appeal from the CMAC would have to involve a legal issue going well beyond the facts of the particular case or, involve a possible miscarriage of justice. Although neither the CMA nor the CMAA recognises the right of a party to appeal directly to the Supreme Court from the Court Martial, s 75 of the Senior Courts Act requires that the Supreme Court must not give leave for such an appeal (apart from an appeal from the Court of Appeal) unless satisfied there are "exceptional circumstances" to justify the appeal.

154 That is, the application for leave must be made within 28 days of the decision under appeal (or within extra time, if granted) and in the manner prescribed by the rules of the court appealed to: CMAA, s 10(3).

155 CMAA, s 24(1). See for example Re Leading Aircraftman F [1998] 1 NZLR 714 (CMAC).

156 CMAA, s 24(2). A finding includes a judgment, decree, order, direction or determination: s 24(4).

157 CMAA, s 24. The Registrar must notify the person who is the subject of the reference by providing a copy of the notice, and asking if he or she desires to have legal representation at any oral hearing: s 24A(1). 
of referrals is to prevent a possible miscarriage of justice from occurring, or to address a disciplinary issue.

These two types of references are not "appeals" in the ordinary sense of the word, but in both cases the Judge Advocate General and the Minister are "requesting" the CMAC to review the matter, and if appropriate, to quash the conviction and make other orders. These references are not in any way connected to the prerogative of mercy. Nothing in the CMAA affects the royal prerogative of mercy. ${ }^{158}$

There are no equivalent provisions in the civilian appeal system. The closest is s 406 of the Crimes Act. Under this section, where the Governor-General has received an application by a person for the exercise of the royal prerogative of mercy (in relation to a conviction or sentence), the GovernorGeneral can either (a) refer the conviction or sentence to the Court of Appeal, and the reference shall be treated as an appeal against conviction or sentence by the person; or (b) can refer a specific question of law to the Court of Appeal to help the Governor-General with the application for mercy, and the Court of Appeal must provide the Governor-General with its opinion. Referrals under s 406 of the Crimes Act will invariably involve fresh evidence. The purpose of these two types of referrals is to prevent a miscarriage of justice from occurring where the convicted person has exhausted all their statutory appeal rights.

The differences between who is the "referrer" in the military and civilian contexts reflects the distribution of responsibility for the overall administration of each sector. In the military sector, the Judge Advocate General is responsible for the "hands-on" administration of Court Martials and appeals from that court, and the Minister of Defence has political responsibility for the overall administration of military justice. In the civilian context, the Governor-General is the representative of the monarch, to whom applications for the royal prerogative of mercy are made, and hence is the appropriate person to refer matters to the civilian Court of Appeal.

\section{J Application of the New Zealand Bill of Rights Act 1990}

As a general proposition, the NZBORA applies to all members of the Defence Force because those members are New Zealand citizens. In the absence of express statutory provisions to the contrary, members of the Defence Force possess the same civil and political rights as persons who are not members of the Armed Forces. Having said this, there are circumstances where some rights in the NZBORA will not apply to service members, or, where the interpretation and application of those rights will be different for service members, compared to ordinary civilians.

There are several provisions in the NZBORA which specifically do not apply in the military context. As already discussed, where a member has elected for summary trial or to be otherwise dealt with summarily, then the accused does not have the right to legal representation, which he or she

158 CMAA, s 27. The references could be made either before or after an application for the prerogative of mercy. 
would otherwise have under s 24(c) of the NZBORA. ${ }^{159}$ Similarly, where the member has elected to be dealt with summarily, he or she does not have the right to a hearing by an independent and impartial court which he or she would otherwise have under s 25(a) of the NZBORA. ${ }^{160}$ The removal of these rights under the NZBORA is not unconstitutional because Parliament is empowered to simply override any provisions in the NZBORA. ${ }^{161}$ Further, the removal of these rights will probably come within s 5 of the NZBORA which permits "reasonable limits prescribed by law as can be demonstrably justified in a free and democratic society".

A final example of the exclusion of application of the NZBORA is s 24(e) of the NZBORA which states that everyone charged with an offence:

... shall have the right, except in the case of an offence under military law tried before a military tribunal,

to the benefit of a trial by jury when the penalty for the offence is or includes imprisonment for 2 years or

more ...

In terms of how particular rights in the NZBORA apply to service members, two cases in particular have suggested a general approach. In Froggatt $v R$, the accused was charged with a number of drug and burglary offences. ${ }^{162}$ The military police had attended the home of the accused who later attended the military police complex where he made a number of damaging admissions. At trial, the defendant argued that his right to consult and instruct a lawyer was breached because he had been arrested and detained. That right is found in s 23(1)(b) of the NZBORA. On appeal against the conviction, the CMAC firstly held the Court is not required to determine if the NZBORA applied to proceedings under the AFDA as the parties had not made submissions on this issue.

The Court held that the appellant had not been under arrest at any stage and had not been "detained" at the police complex. The Court stated that just because a soldier is ordered to attend a particular place, does not mean he or she is thereby under arrest: ${ }^{163}$

... we do not think that the Legislature intended that the Bill of Rights should inhibit or erode the power

of command and obedience to orders which are fundamental to the control and operation of our armed

forces.

159 AFDA, ss 117ZB(2)(a) and 117ZD; and Armed Forces Discipline Regulations, r 15(c)(d).

160 Armed Forces Discipline Regulations, r 15(1)(a)(b); and AFDA, ss 117ZB(2)(b) and 117ZD. The disciplinary officer who determines the matter may be closely connected to the accused and may have personal knowledge of the alleged offence and the investigation. For a detailed discussion of the principles relating to judicial bias see the judgment of Fisher J in Lawrence v R (2001) 1 NZCMAR 414 (CMAC) at [45]-[58].

161 NZBORA is not a supreme or entrenched statute.

162 Froggatt $v$ R, above n 17.

163 At 20. 
The Court held there had not been a breach of s 23(1)(b) of the NZBORA. Implicit in this judgment is the important role of discipline within the Armed Forces and the duty of the service member to obey all lawful directions and orders. Arguably, if the circumstances were civilian in nature, a different result might have ensued.

In $R \quad v$ Jack, military "regulators" (investigators) searched a number of on shore military accommodation facilities, searching for the accused. ${ }^{164}$ Upon entering the accused's cabin, the investigators observed and seized evidence relating to drugs (cannabis pipe and cannabis plant). The appellant was convicted of drug related offences. On appeal, the appellant argued that his right to be protected from "unreasonable search or seizure" under s 21 of the NZBORA had been breached by unreasonable and unlawful searches, and, as a consequence, the evidence obtained by the search should be ruled inadmissible.

The CMAC held that the appellant's s 21 right had not been breached, and the actions of the regulators were not unlawful or unreasonable. The entry of the cabin by the investigators was not a "search" but merely a normal incidence in the undertaking by the regulators of their daily duties: ${ }^{165}$

The quality of privacy applying to the private home of a serviceman may well be equivalent to the quality of privacy attaching to a citizen in his private home. However, the quality of privacy attaching to the accommodation facility in a defence establishment, in respect of an enlisted serviceman, is quite different to that of a citizen or an enlisted serviceman in his own home...

The Court also discussed the scope of "customary powers" under s 97 of the AFDA under which a whole range of non-statutory investigatory and disciplinary actions are available. These include a power to search and seize.

Importantly, the Court stated that the NZBORA did apply to proceedings under the AFDA. ${ }^{166}$ The protection against "unreasonable searches" applied to all persons, including members of the military services. However, the search was not unreasonable and the appeal was dismissed: ${ }^{167}$

Accordingly, the circumstances in which a search might be held to be unreasonable in the civilian context

may not necessarily be held to be unreasonable in the context of service in the armed forces.

$164 R$ v Jack [1999] 3 NZLR 331 (NZCMAC).

165 At 336

166 At 339

167 At 339 
And: 168

We conclude that although the NZBORA has a place in the law relating to armed forces discipline, the proper exercise of powers arising from statute, or preserved in relation to service custom, will not ordinarily create circumstances in which the NZBORA can be pleaded.

In Van der Ent $v$ Sewell, the applicant applied for a writ of habeas corpus. ${ }^{169}$ The applicant had been detained and a court martial was due to be held in approximately two weeks. McGechan J refused the application for habeas corpus ${ }^{170}$ but considered the issue of whether the applicant could be released on bail pending the court martial. McGechan J referred to s 24(b) of the NZBORA and stated: ${ }^{171}$

[10] I have no doubt that s 24 and that paragraph apply in relation to military disciplinary proceedings. It is not a question which has been decided in finite terms to this point, but all the indications so favour, not least those in s 24(e) which makes a specific exception in relation to jury trials for offences under military law tried before a military tribunal. That would hardly be necessary if s 24 did not include matters military.

I am prepared to say the present applicant is charged with an "offence", under s 24 meaning in any event, and the question is whether there is "just cause" for continued detention pending a determination by Courts-Martial or otherwise of the alleged offence or offences.

In deciding whether there was just cause for release, McGechan J stated that "due regard, and it should be anxious regard, must be paid to the military context and the need to maintain discipline within military forces. It is a special situation." ${ }^{172}$ His Honour granted bail upon conditions.

This is an important case because it shows a civilian judge grappling with a bail decision in the special circumstances of the applicant facing a forthcoming Court Martial. McGechan J relied on the NZBORA rather than bail laws, or any provision in the AFDA, to grant bail.

\section{K Discussion}

What does the above comparison show? It is suggested that it shows three things. First, although the principal civilian criminal justice statutes do not apply to the military system, the Court Martial

168 At 340

169 Van der Ent $v$ Sewell [2000] 3 NZLR 125 (HC).

170 On the grounds that the application was more suitable for judicial review as it challenged the exercise of a discretion (by the Chief of Defence Force under s 52(3)(b) of the Defence Act), rather than directly challenging the lawfulness of the detention [5]-[8]. His Honour hinted that if judicial review was to commence, an important factor to be taken into account was "discretionary factors relating to interference with the discharge of armed forces disciplinary procedures" (at [6]).

171 Van der Ent $v$ Sewell, above n 169.

172 At [11]. 
and the CMAC apply the same general approaches and principles as those found in the civilian statutes. This can be seen in terms of rules of evidence, procedure, sentencing and bail. The civilian laws have been adopted and adapted.

Second, the comparison also shows that the right to appeal various decisions of the Court Martial are essentially the same as equivalent rights in the civilian system. The procedure for appeals to the CMAC (Court Martial Appeal Court Rules) are virtually identical to those applicable in the Court of Appeal (Court of Appeal (Criminal) Rules). Again, civilian laws have been adopted and adapted. The major differences between the two appellate systems is that (in respect to conviction appeals) the CMAC retains the common form "proviso" and (in respect to sentence appeals) lacks a power to remit a sentence back to the Court Martial.

Thirdly, the comparison shows that whilst in general the NZBORA applies to all members of the Armed Forces, the way in which the NZBORA has been applied in the military context is somewhat different to the civilian context. These differences reflect the special obligations and responsibilities of members of the Armed Forces.

Despite all of the similarities between the two systems, it is suggested that a number of fundamental or "core" features of the military system are unlikely to change in the near future. These features are:

(i) The role of the military members as fact finders differs from the civilian jury in several key respects. First, the military members are not truly "impartial" in the sense that each military member brings with him or her a deep understanding of the relative seriousness of particular offences, the importance of discipline within the Armed Forces and an ability to judge the liability of the accused person in the broader military context. Indeed, these attributes are seen as strengths of the military member system. Secondly, the military members, with the judge, determine an appropriate sentence, again, informed by an understanding of what would constitute an appropriate and proportionate sentence. Thirdly, only three or five members are required for a trial. It is unlikely that any of these characteristics will change in the near future;

(ii) In general, none of the key civilian statutes apply to proceedings in the Court Martial or the CMAC. Instead, the military system has its own set of statutes which set out substantive law, procedural law and sentencing law. In this sense the governing legislation for military trials and appeals is sui generis and again, it is unlikely that this will change in the near future;

(iii) When imposing a term of imprisonment, the Court Martial does not set minimum terms of imprisonment or non-parole periods. Civilian sentencing courts can also decline to set a minimum term or non-parole period. However, in the civilian system, statutory minimum periods are set whilst in the military system, this is a matter of discretion for the Reconsidering Authority; and

(iv) The NZBORA does not apply to members of the Armed Forces in the same way as it applies to civilians. 
These fundamental differences reflect the different histories of the two systems and the different needs of the relevant institutions and personnel. The seven key principles identified in the introduction (maintenance of discipline, consistency, portability, expedition, fairness, efficiency and simplicity) remain the key drivers of the military criminal justice system.

\section{Conclusion}

There is a clear pattern whereby the military justice system is adopting and adapting more and more features of the civilian justice system, where this is appropriate. ${ }^{173}$ In this sense the military and civilian systems are becoming aligned. For the future, however, the overall legal framework for the administration of military criminal justice is unlikely to change, and indeed there is no assumption that it should change. The civilian criminal justice system is not exactly immune from criticism. The military justice system has developed, and will continue to evolve, to meet the specific needs of the institutions and personnel affected, just as the civilian system has developed and will continue to evolve to meet the needs of its institutions and persons involved.

173 As already mentioned, the Military Justice Legislation Amendment Act further develops this alignment process by attempting to ensure that the victims of crime in military offences have the same rights as civilian victims; that the military procedures for determining fitness to stand trial are consistent with the provisions of the Criminal Procedure (Mentally Impaired Persons) Act; that prosecution rights to object to appointment of military members are expanded; and that changes are made to the onus of proof. The military system does already accord victims of crime a range of rights: see Manual of Armed Forces Law Volume 1: Commander's Handbook on Military Law, above n 11, s 7. 
